J. Perinat. Med. 11 (1983) 43

\title{
Fetal oxygen affinity and its parameters in a random obstetric population
}

\author{
R. G. Farquharson
}

\section{Introduction}

The exchange of oxygen from mother to fetus has been investigated for many years since the first demonstration in 1884 of oxygen uptake via the umbilical circulation. A detailed review of modern observations was recently made by MESCHIA [6]. In the 1930's two characteristics were demonstrated. Firstly the high oxygen affinity of fetal blood compared to maternal and secondly, the low oxygen pressure $\left(\mathrm{P}_{\mathrm{O}_{2}}\right)$ circulating in the fetus. The latter observation led to the perplexing consideration that the fetus was in a state of constant hypoxemia compared to mother and can be equated with the situation that mountaineers would experience on Mt. Everest.

The high oxygen affinity of fetal blood is best thought of as offering a suitable adaptation to the fetal environment. Being entirely dependent on the maternal circulation for uptake of oxygen across the placenta, it is seen as a logical step to increase the oxygen affinity in the fetus so that fetal uptake is selectively favoured to that of the maternal tissues.

In general, oxygen affinity is described by a graph (the oxygen dissociation curve). A typical curve for adult and term fetal blood is shown in Fig. 1. This graph illustrates the high oxygen affinity (lower P50) of fetal blood compared to that of adult of maternal blood.

There are numerous factors which affect the oxygen affinity of fetal blood.

\section{Curriculum vitae}

ROY FARQUHARSON was born in 1951 in Aberdeen, Scotland. He studied medicine at Aberdeen University from which he graduated in 1975. Since 1975 he has worked as a resident in obstetrics and gynaecology, paediatrics and general surgery before specialist training at Aberdeen Maternity Hospital and National Women's Hospital, Auckland, New Zealand. Main fields of interest: Perinatal medicine and physiology.

\section{$1.1 \mathrm{pH}$}

A fall in $\mathrm{pH}$ or rise in acidity means a rise in P50 or fall in oxygen affinity.

\subsection{2,3-Diphosphoglycerate alteration of P50}

$\mathrm{pH}$ alteration of oxygen affinity is partly achieved through an effect on 2,3-diphosphoglycerate (2,3-DPG) production within the red blood cell. 2,3-DPG binds to the deoxy form of haemoglobin in the space between the beta chains (with the aid of adenosine triphosphate (ATP)) and this must be expelled from the molecule as it changes to the oxy-form (when this space closes up). 2,3-DPG combines with $\mathrm{Hb}$ and thus allows less oxygen to bind with $\mathrm{Hb}$ such that a fall in 2,3-DPG means a

○ by Walter de Gruyter \& Co. · Berlin · New York 


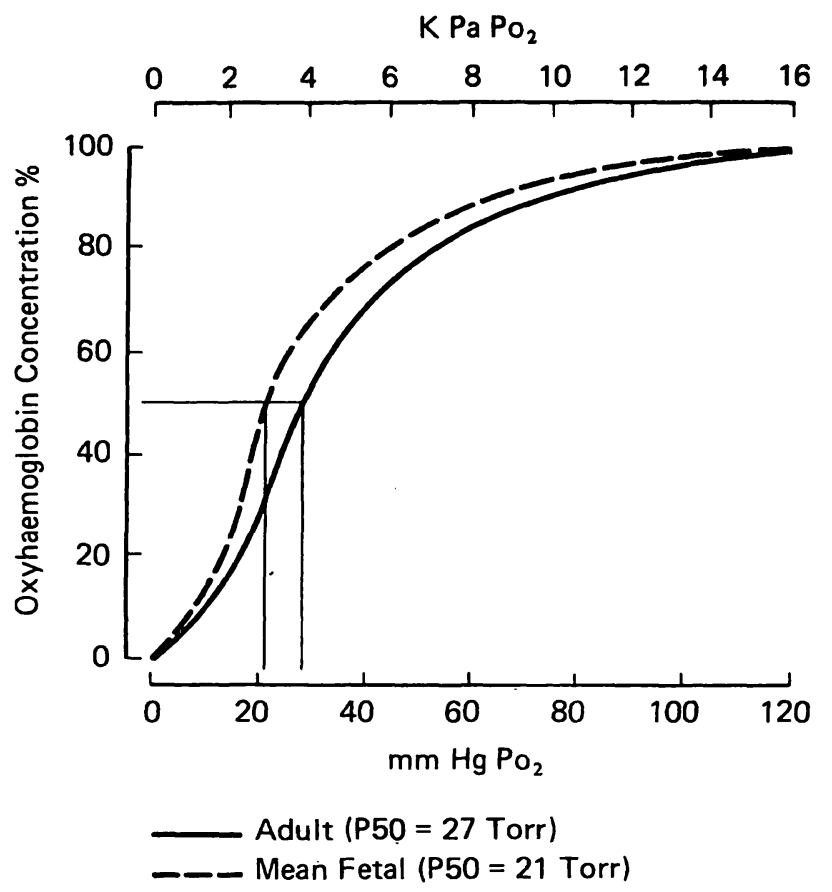

Fig. 1. Oxygen dissociation curve (o.d.c.) of adult and fetus at term.

fall in the P50 or increased oxygen affinity. 2,3-DPG has the highest of all organic phosphate concentrations within the red cell and alters the haemoglobin molecule such that oxygen affinity is directly affected [3].

\subsection{Carbon monoxide}

Haemoglobin combines more readily with carbon monoxide than it will with oxygen to form carboxyhaemoglobin. This reduces the amount of haemoglobin available for oxygen transport thus decreasing the P50 or increasing the oxygen affinity.

\subsection{Carbon dioxide}

With carbon dioxide the reverse situation is seen and is called the BOHR effect. Increasing carbon dioxide concentrations produce a decrease in oxygen affinity directly and by increasing the acidity, thus favouring oxygen release in the tissues.

\section{$1.5 \mathrm{HbA} / \mathrm{HbF}$ ratio}

The ratio of adult to fetal haemoglobin also affects the P50 of fetal blood. Fetal haemoglobin has a higher oxygen affinity than adult haemoglobin in vivo. The effect of DPG on the P50 of $\mathrm{HbA}$ is calculated to be 2.5 times greater than that on the P50 of $\mathrm{HbF}$ [7]. It could be said that the oxygen affinity of $\mathrm{HbF}$ is less affected by $\mathrm{DPG}$ concentration than is adult haemoglobin. $\mathrm{HbA} /$ $\mathrm{HbF}$ ratio is intimately related to birthweight. In the mature term infant the smaller the baby the greater the HbF content of fetal blood [2].

\section{Materials and methods}

Twenty-two $3 \mathrm{ml}$ samples of umbilical cord arterial and venous blood were drawn into heparinised syringes from double clamped cord samples taken immediatly after delivery from a random obstetric population. The samples were then analysed in the following manner:

\subsection{Blood gas analysis}

Using the instrumentation Laboratory IL Micro 613 Blood Gas Analyser, measurement of cord arterial and venous $\mathrm{pH}, \mathrm{P}_{\mathrm{O}_{2}}, \mathrm{P}_{\mathrm{OO}_{2}}$ and Base Excess (B.E.) were performed. The accuracy of the system is as follows:

Standard Deviation

$\mathrm{pH} \pm 0.008$

$\mathrm{P}_{2} \pm 0.16 \mathrm{KPa}$

$\mathrm{P}_{\mathrm{CO}_{2}} \pm 0.07 \mathrm{KPa}$

B.E. $\pm 1 \mathrm{mmol} / 1$

\subsection{Oxygen affinity curve}

Two microlitres of heparinised cord venous blood less than 12 hours old and kept in ice was used. The samples were placed on a cover glass and covered with a gas permeable membrane. The sample was then, in accordance with the manufacturer's instructions, placed on the Hem-O-Scan Analyzer (V.A. HowE Ltd.) and the oxygen dissociation curve produced. From the curve, the P50 was measured. The figure was then corrected to a $\mathrm{pH}$ of 7.40 using the equation: $0.48 \times \mathrm{pH}-$ measured $\log \mathrm{P} 50=$ corrected $\log \mathrm{P} 50$. (Where $\mathrm{pH}=$ Venous $\mathrm{pH}-7.40$ ). The Hem-O-Scan analyzer reproduced a P50 result within a standard deviation of 0.08 torr. 
Tab. I. Blood gas analysis on cord arterial and venous samples.

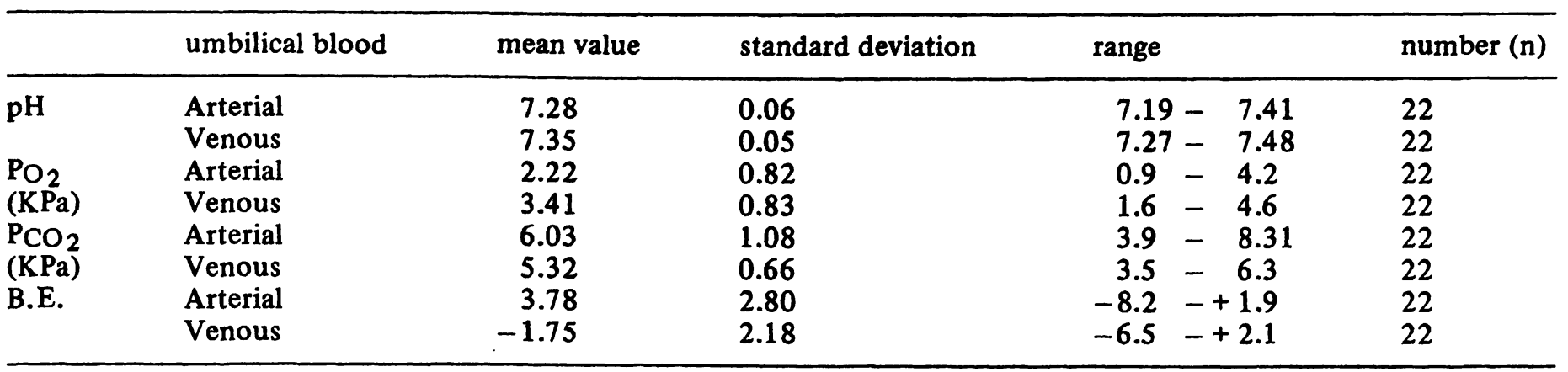

\subsection{2,3-Diphosphoglycerate concentration}

This was determined by a modified method of LOWRY. $1 \mathrm{ml}$ of heparinised cord blood was mixed with $3 \mathrm{mls}$ trichloroacetic acid and stored at $4^{\circ} \mathrm{C}$. After centrifugation, the supernatant was removed. 2,3-DPG levels remain stable for up to two weeks using this method (SIGMA CHEMICAL Co.). 2,3-DPG levels were measured using an enzymatic coupling system. The reaction is monitored spectrophotometrically at $340 \mathrm{~nm}$ to produce a quantitative measurement (SIGMA TECHNICAL BUlletin No. 35 - UV). The measured level of 2,3-DPG was calculated from the equation -

$$
\frac{(\text { Initial } \Delta \mathrm{A} 340-\text { Final } \Delta \mathrm{A} 340-0.030)}{\text { PCV }} \times
$$

$$
\text { × } 7.7 \times 100=\text { Packed Cell 2,3-DPG (Mmol/l) }
$$

The corrected $\Delta \mathrm{A}$ (Initial $\Delta \mathrm{A} 340$-Final $\Delta \mathrm{A} 340$ 0.030 ) never exceeded 0.550 and thus allowed an assay to be performed in accordance with the kit manufacturers instructions, with a standard deviation of $0.08 \mathrm{mmol} / 1$. Packed cell volume (PCV) was estimated shortly after sampling.

\subsection{Selection of patients}

A random selection of cord samples was performed on 22 deliveries. All pregnancies were uncomplicated prior to the onset of labour and were full or post term. This was verified by neonatal examination by a peadiatrician after delivery.

\section{Results}

\subsection{Blood gas analysis}

The results of analysis for $\mathrm{pH}, \mathrm{P}_{\mathrm{O}_{2}}, \mathrm{P}_{\mathrm{CO}_{2}}$ and B.E. are given in Tab. I including the mean, standard deviation and range of values.

\subsection{Oxygen affinity (P50)}

The oxygen affinity of the analysed samples given as P50 (TORR) is given in Tab. IIa. The values given are in agreement with those given by RIEGEL and VERSMOLD [8].

\subsection{2,3-Diphosphoglycerate concentrations}

Similarly in Tab. II, the 2,3-DPG level is tabulated with mean value, standard deviation and range of

Tab. II a. Oxygen affinity, 2,3-diphosphoglycerate concentrations and packed cell volume in cord venous sample.

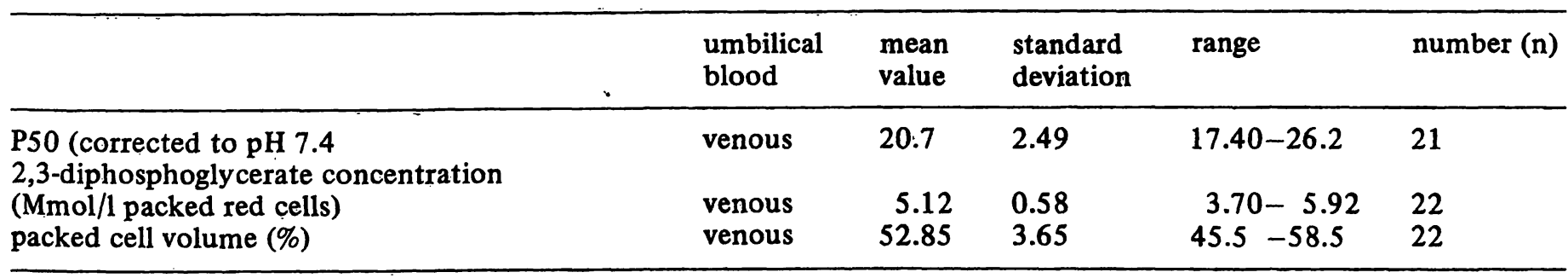


Tab. IIb. Original data for umbilical cord artery and vein gas analysis, umbilical vein oxygen affinity valve (P50), 2,3-DPG concentration packed cell volume

\begin{tabular}{rlllllllllll}
\hline & $\begin{array}{l}\mathrm{pH} \\
\text { arterial }\end{array}$ & venous & $\begin{array}{l}\mathrm{PO}_{2} \\
\text { arterial }\end{array}$ & venous & $\begin{array}{l}\text { PCO } \\
\text { arterial }\end{array}$ & venous & \multicolumn{2}{c}{ base excess } \\
arterial & venous & P50 & $2,3-D P G ~ P C V$ \\
\hline 1 & 7.32 & 7.35 & 1.8 & 3.5 & 6.0 & 5.4 & -0.8 & -0.7 & 24.9 & 5.18 & 45.0 \\
2 & 7.32 & 7.35 & 2.2 & 3.4 & 6.64 & 5.52 & -0.4 & 0.0 & 22.4 & 5.45 & 51.0 \\
3 & 7.24 & 7.33 & 1.5 & 1.6 & 6.24 & 6.19 & -5.7 & +0.6 & 21.2 & 4.86 & 54.5 \\
4 & 7.41 & 7.48 & 1.6 & 2.4 & 4.78 & 3.5 & +0.8 & +1.7 & 18.3 & 5.60 & 58.0 \\
5 & 7.37 & 7.44 & 2.6 & 3.7 & 5.92 & 4.63 & +2.1 & +1.9 & 20.1 & 5.34 & 58.0 \\
6 & 7.22 & 7.32 & 1.6 & 4.3 & 8.31 & 5.87 & -2.2 & -1.9 & 18.2 & 5.41 & 53.0 \\
7 & 7.22 & 7.29 & 2.6 & 3.8 & 6.27 & 5.9 & -6.4 & -3.1 & 17.4 & 4.27 & 56.0 \\
8 & 7.23 & 7.31 & 2.0 & 3.3 & 6.65 & 4.72 & -4.3 & -3.4 & 22.7 & 4.52 & 56.0 \\
9 & 7.21 & 7.35 & 2.6 & 3.5 & 5.71 & 4.45 & -8.2 & -3.9 & 25.7 & 5.79 & 56.0 \\
10 & 7.23 & 7.27 & 1.8 & 2.5 & 7.6 & 6.3 & -3.0 & -2.8 & 17.4 & 5.3 & 53 \\
11 & 7.30 & 7.36 & 2.8 & 4.6 & 6.26 & 4.92 & -2.4 & -1.2 & 19.1 & 5.38 & 58.5 \\
12 & 7.32 & 7.37 & 1.9 & 2.9 & 7.28 & 5.07 & -6.0 & -0.3 & 17.8 & 5.36 & 51.5 \\
13 & 7.33 & 7.41 & 2.5 & 4.0 & 4.86 & 4.63 & -4.5 & +0.3 & 22.5 & 5.67 & 52.0 \\
14 & 7.24 & 7.28 & 2.7 & 3.8 & 5.67 & 4.63 & -7.2 & -6.5 & 21.7 & 5.48 & 54.0 \\
15 & 7.31 & 7.4 & 4.2 & 4.3 & 4.3 & 3.9 & -8.0 & +0.1 & 18.0 & 5.29 & 57.5 \\
16 & 7.21 & 7.30 & 1.0 & 2.4 & 5.7 & 4.8 & -8.0 & -5.2 & 19.6 & 5.92 & 50.0 \\
17 & 7.34 & 7.35 & 1.8 & 2.5 & 5.4 & 5.39 & -1.4 & -0.4 & 20.0 & 5.05 & 49.5 \\
18 & 7.28 & 7.36 & 2.8 & 4.3 & 5.9 & 5.4 & -3.1 & -0.4 & 20.2 & 3.70 & 56.0 \\
19 & 7.19 & 7.29 & 0.9 & 2.5 & 6.36 & 5.34 & -7.9 & -4.3 & 19.9 & 4.11 & 56.5 \\
20 & 7.40 & 7.48 & 3.8 & 3.2 & 4.96 & 4.13 & -2.4 & -0.4 & 26.2 & 5.47 & 47.5 \\
21 & 7.24 & 7.34 & 1.6 & 4.1 & 6.68 & 4.9 & -4.0 & -3.2 & 15.5 & 4.90 & 50.5 \\
22 & 7.27 & 7.36 & 2.6 & 4.5 & 7.0 & 5.5 & -1.5 & 0.0 & 19.60 & 4.57 & 52.5 \\
& & & $\mathrm{KPa}$ & $\mathrm{KPa}$ & $\mathrm{KPa}$ & $\mathrm{KPa}$ & & & TORR & $(\mathrm{Mmol} / \mathrm{L})(\%)$ \\
\hline
\end{tabular}

value. The values given correlate well with previous studies $[5,11]$.

\subsection{Obstetric and neonatal outcome}

Obstetric outcome. Of the 22 patients there were 14 spontaneous vertex deliveries, 4 HAIIG FERGUSON forceps and 4 ceasarean sections. The indications for the forceps deliveries were previous ceasarean section (1), delay in second stage (2) and mild pre-eclampsia (1). The four ceasarean sections were performed for fetal distress in first stage (1) cephalo pelvic disproportion (3).

Neonatal outcome. APGAR scores were all greater than 5 at 1 minute and 7 at 5 minutes. There were two cases of intra-uterine growth retardation (2750 gm and $2520 \mathrm{gms})$. The remaining babies all weighed between 2,800 and 3,700 grams. The maturity was assessed by sure menstrual data in all patients and by paediatric assessment after delivery. All babies were found to be at term \pm 12 days.

Fetal abnormality. There were three cases of fetal abnormality:
Baby 1. The baby was spontaneously delivered following induction of labour at term plus 11 days

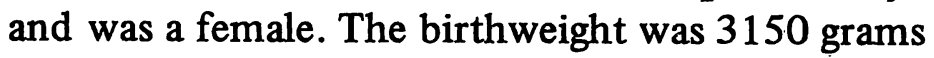
and the APGAR score was 6 at 1 minute and 9 at 5 minutes. The baby had a moderate encephalocele but otherwise no other neural tube or physical abnormality was noted, and the baby survived.

Baby 2. The baby was delivered spontaneously at term, associated with meconium stained liquor and was a female. The birthweight was 2820 grams and the APGAR scores were 5 at 1 minute and 7 at 5 minutes. The baby eventually became cyanosed shortly after birth and was thought to have meconium aspiration phneumonia. The baby developed renal failure and died at 5 days of age. Postmortem studies showed a moderate degree of pulmonary hypoplasia and a severe renal hypoplasia along with coarctation of the aorta.

Baby 3. The baby was delivered spontaneously at term and was female. The birthweight was 3590 grams and the APGAR scores were 9 at 1 minute and 9 at 5 minutes. The baby developed cyanosis and cardiac failure. Cyanotic congenital heart disease was diagnosed and was confirmed by 
Tab. III. Results of three fetal abnormalities with reference to umbilical artery and venous measurements of $\mathrm{pH}, \mathrm{PO}_{2}$, $\mathrm{PCO}_{2}$, base excess, oxygen affinity, (P50), 2,3-DPG and packed cell volume.

\begin{tabular}{llllllllllll}
\hline & $\begin{array}{l}\mathrm{pH} \\
\mathrm{A}\end{array}$ & $\mathrm{V}$ & $\begin{array}{l}\mathrm{PO}_{2} \\
\mathrm{~A}\end{array}$ & $\mathrm{~V}$ & $\begin{array}{l}\mathrm{PCO}_{2} \\
\mathrm{~A}\end{array}$ & $\mathrm{~V}$ & $\begin{array}{l}\text { B.E. } \\
\mathrm{A}\end{array}$ & $\mathrm{V}$ & $\mathrm{P50}$ & $\begin{array}{l}2,3 \\
\mathrm{DPG}\end{array}$ & $\mathrm{PCV}$ \\
\hline $\begin{array}{l}\text { baby 1 } \\
\text { encephalocele } \\
\text { baby 2 } \\
\begin{array}{l}\text { pulm. hypoplasia renal } \\
\text { baby 3 }\end{array}\end{array}$ & 7.23 & 7.31 & 1.0 & 3.3 & 6.65 & 4.72 & -43 & -3.4 & 22.7 & 4.52 & 56. \\
pulm. trunk atresia & 7.32 & 7.37 & 1.9 & 2.9 & 7.28 & 5.07 & -6.0 & -0.3 & 17.8 & 5.36 & 51. \\
\hline
\end{tabular}

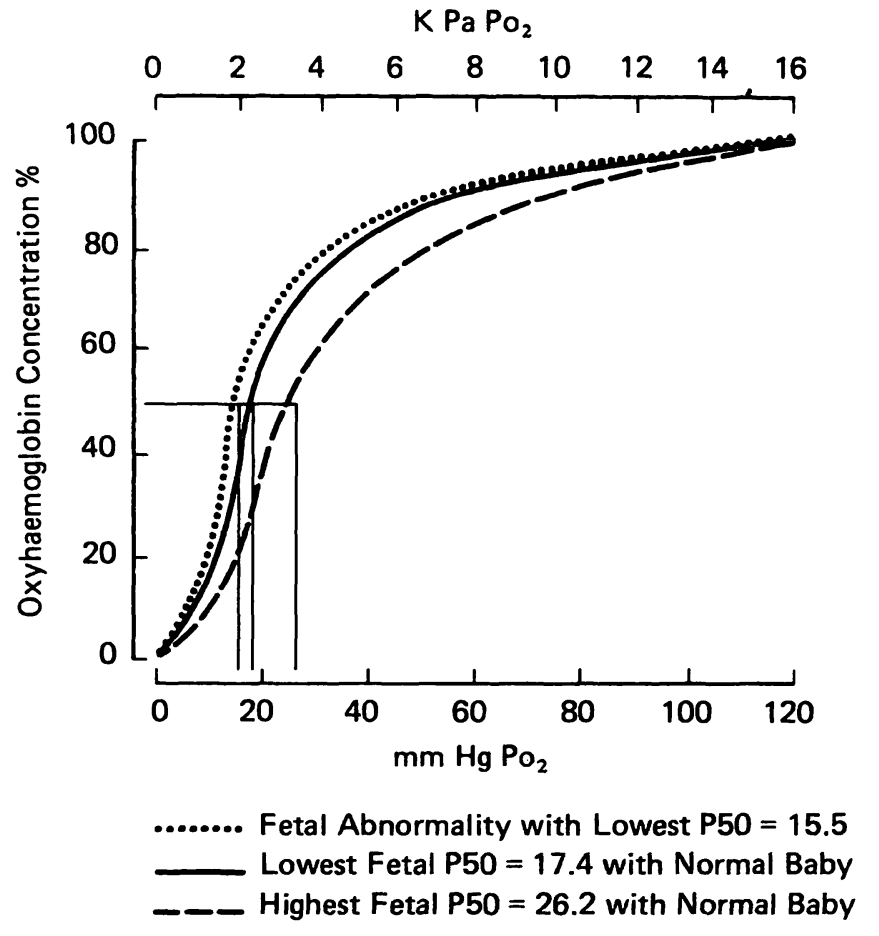

Fig. 2. Fetal oxygen dissociation curves of three babies lowest values for normal babies with low value for baby with fetal abnormality. cardiac catheterisation and the defect repaired surgically, shortly after birth. Unfortunately, the baby died at 3 days of age. Postmortem findings showed pulmonary trunk atresia, a large ventricular septal defect and discordant ventricles.

All babies were found to have normal haemoglobin values at birth. The expanded results from these babies is given in Fig. 2 and Tab. III.

A group of normal and growth retarded term infants was studied. Oxygen affinity and 2,3diphosphoglycerate concentrations were measured on umbilical venous blood. Umbilical arterial $\mathrm{pH}$ was measured at birth.

The results are summarised in Tab.IV.

\section{Discussion}

The study of oxygen affinity of human fetal blood has been well reviewed recently [8]. Little has been done to study its alteration with obstetrical

Tab. IV. Study of oxygen affinity, umbilical arterial pH, 2,3-diphosphoglycerate concentration in normal and growth regarded neonatal population.

\begin{tabular}{lllll}
\hline normals & P50 & umbilical arterial $\mathrm{pH}$ & 2,3-DPG & birthweight (gms) \\
\hline 1 & 19.8 & 7.23 & 5.58 & 3140 \\
2 & 21.9 & 7.38 & 5.23 & 3200 \\
3 & 26.2 & 7.34 & 5.86 & 3050 \\
4 & 23.2 & 7.30 & 4.90 & 4000 \\
5 & 25.5 & 7.35 & 5.30 & 4690 \\
IUGR & & & & \\
1 & 23.6 & 7.19 & 4.01 & 2380 \\
2 & 21.8 & 7.28 & 4.7 & 2590 \\
3 & 26.3 & 7.08 & 5.1 & 2450 \\
4 & 17.7 & 7.18 & & \\
\hline
\end{tabular}


and neonatal outcome. The large range of P50 values are well within the known limits of P50 for fetal blood. One of the most interesting findings was that 2 babies with fatal illnesses had the two lowest P50 values or highest oxygen affinity. VERSMOLD et al. [10] showed in their study of oxygen transport in congenital heart disease that P50 values were low or normal during the first 50 days, and then elevated after the third month of life. However, the estimations were taken at 5 days of age and were not lower than 20 TORR. In the present study both the babies with congenital heart disease had the lowest P50 values at 17.8 and 15.5 TORR respectively. There was no obvious difference in the 2,3-DPG levels recorded in these two cases when compared to the group as a whole, as was found by VERSMOLD et al. It was found that arterial $\mathrm{pH}$ was similar to the group as a whole at birth which suggests that $\mathrm{pH}$ alteration of oxygen affinity was not an important factor at this stage.

2,3-diphosphoglycerate is an important variable in the alteration of the P50 value. 2,3-DPG concentration in normal and hypertensive mothers and their babies was studied by WEISS et al. [11]. In their study no difference in the 2,3-DPG levels were found between the normal and hypertensive groups, the latter containing two small for dates infants out of 11 babies. No other oxygenation parameters were measured in their study. In contrast to this small-for-dates population, a study of four small-for-dates babies showed lowered 2,3-DPG values, compared to a normal group (Tab.IV).

Despite this lower 2,3-DPG concentration no obvious alteration of the P50 curve was evident.
2,3-DPG levels were lowered due possibly to the lower $\mathrm{pH}$ of this group compared to the normals [1].

A decrease in oxygen affinity (high P50 value) of blood enhances the release of oxygen from haemoglobin to the tissues [9] and compensates for the decreased cardiac output and/or reduced oxygen content of blood [4]. The accepted assumption that a high P50 value implies an increased oxygen unloading capacity of blood is not applicable at low arterial tensions [8], i.e., on the steep part of the oxygen dissociation curve. With this in mind, the BOHR shift becomes an important factor in favouring the unloading of oxygen from maternal to fetal blood, and from fetal blood to fetal tissues. It is useful for the fetus to have a low P50 to obtain oxygen from the mother but as a consequence it impairs release of oxygen to the tissues unless the BOHR effect is favourable. It is as perplexing to reason why the two babies with cardio-pulmonary anomalies should have the lowest P50 values. If it is to enhance survival in extra-uterine environment, then perhaps some intrauterine adaptation might be taking place secondary to fetal maldevelopment. This adaptation may have numerous stimuli but the common problem between these two babies was the presence of compromised circulation, e.g., pulmonary hypoplasia and pulmonary trunk atresia. The presence of marked renal hypoplasia may also be relevant. Further research in this area may help to clarify the compensatory roles of fetal oxygenation determinants in pregnancies associated with intra uterine growth retardation and cardiopulmonary anomalies.

\section{Summary}

Fetal oxygenation studies have provided the obstetrician with some basic information regarding oxygen supply to the fetus. Although standard values for normal fetuses at term have been made, little has been done to evaluate any changes occurring with fetal and neonatal abnormality. Twenty-two sets of analyses were performed to measure oxygen affinity (P50) 2,3-diphosphoglycerate concentration and full blood gas analysis on umbilical arterial and venous samples. The samples were taken from a random obstetric population. All babies, were at term or post term by antenatal data and paediatric assessment at delivery. A further study was performed on a group of

normal and growth retarded term infants, assessing the same parameters as the random population.

Following analysis, 2 cases of cardio-pulmonary abnormality, resulting in neonatal death, were found to have the highest oxygen affinity, the remaining oxygenation parameters of $\mathrm{PO}_{2}, \mathrm{PCO}_{2}, \mathrm{pH}$ and 2,3-diphosphoglycerate concentration were found to be similar to the rest of the group. The results of this study agree with previous investigative findings for the normal babies. The finding of low P50 (or high oxygen affinity) in these 2 cases is an unusual finding and may reflect an adaptive function towards extra-uterine life. 
No alteration of fetal oxygen affinity was found in a small group of growth retarded babies despite the lowering of the 2,3-diphosphoglycerate concentration. The latter finding probably reflects the lowered intrauterine fetal blood $\mathrm{pH}$ found with growth retarded babies. Further research is required to elucidate the comples process of fetal oxygenation that occurs in the presence of fetal abnormality.

Keywords: Cardio-pulmonary abnormality, intrauterine growth retardation, oxygen affinity, 2,3-diphosphoglycerate concentration.

\section{Zusammenfassung}

Parameter der fetalen Sauerstoffaffinität - Untersuchungen an einem randomisierten geburtshilflichen Kollektiv Untersuchungen über die fetale Oxygenierung haben dem Geburtshelfer einige grundlegende Informationen hinsichtlich der Sauerstoffversorgung des Feten geliefert. Man hat Normalwerte für gesunde Feten am Termin aufstellen können; über Abweichungen bei fetalen und neonatalen Komplikationen gibt es jedoch nur wenige Daten.

Wir haben 22 Versuchsansätze analysiert, um die $\mathrm{O}_{2}$ Affinität (P50), die 2,3-Diphosphoglycerat-Konzentration und die Blutgaswerte sowohl im arteriellen wie im venösen Blut zu bestimmen. Die Proben stammten aus einem randomisierten geburtshilflichen Kollektiv. Alle Neugeborenen waren an bzw. über dem Termin, wobei antenatale Daten sowie die pädiatrische Untersuchung kurz nach der Geburt zugrunde gelegt wurden. Eine weitere Untersuchung führten wir bei einer Gruppe von gesunden und wachstumsretardierten Kindern am Termin durch; die Einstufung erfolgte nach den gleichen Kriterien wie im randomisierten Kollektiv.

Schlüsselwörter: Cardio-pulmonare Komplikationen, 2,3-Diphosphoglycerat-Konzentration, intrauterine Wachstumsretardierung, $\mathrm{O}_{2}$-Affinität.

\section{Résumé}

Affinité foetale pour l'oxygène et ses paramètres dans une population obstétricale randomisée

Les études sur l'oxygénation foetale ont fourni aux obstétriciens quelques informations de base sur l'apport d'oxygène au foetus. Bien que des valeurs standards aient été établies chez le foetus normal à terme, on a peu fait pour évaluer les modifications survenant en cas d'anomalies foetales et néonatales.

22 lots d'analyse ont été réalisés pour mesurer l'affinité d'oxygène (P50), la concentration de 2,3-diphosphoglycerate et l'analyse complète des gaż du sang sur des échantillons de sang ombilical artériel et veineux. Les échantillons provenaient d'une population obstétricale randomisée. Tous les enfants étaient à terme ou post terme sur les données anténatales et sur l'examen pédiatrique à la naissance. Une étude complémentaire a été effectuée sur un groupe d'enfants normaux et d'enfants hypotrophiques, en analysant les mêmes paramètres que pour la population randomisée.

A la suite des analyses, on a trouvé que 2 cas d'anomalies cardio-pulmonaires, ayant abouti à une mort néonatale,
Die Analyse ergab, daß in 2 Fällen mit einer cardiopulmonaren Komplikation, die auch zum Tod in der Neonatalphase führte, die höchste $\mathrm{O}_{2}$-Affinität gefunden wurde, während die anderen Parameter wie $\mathrm{PO}_{2}, \mathrm{PCO}_{2}$, pH und 2,3-Diphosphoglycerat-Konzentration mit den Werten aus der Gruppe vergleichbar waren. Diese Daten stimmen auch mit früheren Untersuchungen an gesunden Kindern überein. Die Tatsache, daß der P50 in diesen beiden Fällen niedrig (bzw. die $\mathrm{O}_{2}$-Affinität hoch) war, ist ungewöhnlich und könnte als adaptiver Prozeß an das extra-uterine Leben gedeutet werden.

In einer kleinen Gruppe von wachstumsretardierten Neugeborenen fand sich keine Änderung der fetalen $\mathrm{O}_{2}$-Affinität, abgesehen von einer Abnahme der 2,3Diphosphoglycerat-Konzentration. Diese läßt sich möglicherweise durch den herabgesetzten $\mathrm{pH}$ im Fetalblut von wachstumsretardierten Neugeborenen erklären. Es sind weitere Untersuchungen erforderlich, um in die komplexen Vorgänge der fetalen Oxygenierung bei komplikationsbehafteten Feten Klarheit zu bringen.

Mots-clés: Affinité d'oxygène, anomalie cardio-pulmonaire, concentration en 2,3-diphosphoglycerate, retard de croissance intra-utérin.

Acknowledgements: I would like to thank Dr. RUFUS WELLS, Professor G. C. LIGGIN, and Sir A. W. LILEY for their early encouragement and advice. Thanks are also due to Professor I. MACGILLIVRAY for his help and to JOYCE POSTMA and FIONA MACGREGOR for their technical assistance. 


\section{Bibliography}

[1] ASAKURA, T., Y.SATO, S. MINAKAMI, H. YOSHIKAWA: $\mathrm{pH}$ depency of 2,3-diphosphyglycerate in red blood cells. Clin. Chim. Acta. 14 (1966) 840

[2] BARD, H.: The effect of placental insufficiency on fetal and adult haemoglobin synthesis. Amer.J. Obstet. Gynec. 120 (1974) 67

[3] BARD, H., F. TEASDALE: Red cell oxygen affinity haemoglobin typ, 2,3-diphosphoglycerate and $\mathrm{pH}$ as a function of fetal development. Paediatrics 64 (1979) 483

[4] BAUER, C.: On respiratory function of haemoglobin. Rev. Physiol. Biochem. Pharacol. 70 (1974) 1

[5] DELIVORIA PAPADOPOULOS, M., M. P. RONCLEVIC, F. A. OSKI: Postnatal changes in osygen transport of term, pre-term and sick infants. The role of red cell 2,3-diphosphoglycerate and adult haemoglobin. Pediat. Res. 5 (1971) 235

[6] MESCHIA, G.: Evolution of thinking in fetal respiratory physiology. Amer. J. Obstet. Gynec. 132 (1978) 806

[7] ORZALES, M. M., W. W. HAY: The relative effect of 2,3-diphosphoglycerate on the oxygen affinity of fetal and adult haemoglobin in whole blood. Experientia 15 (1973) 1480

[8] RIEGEL, K. P., H. T. VERSMOLD: Respiratory gas transport characteristics of blood and haemoglobin in perinatal physiology. Plenum Medical Book, London 1977
[9] VERSMOLD, H., B. BRAUSER: Improved cellular oxygenation by 2,3-diphosphyglycerate: Quantitative measurement of tissue hypoxia by registration of absorption spectra of cytochrome and haemoglobin in the intact organg. In: GERLACH, E., K. MOSER, W. EILMANN (eds.): Erythrocytes, thrombocytes, leucocytes. Thieme, Stuttgart 1973

[10] VERSMOLD, H. T., C. WINDERKAMP, C. DOHLEMANN, K. P. RIEGEL: Oxygen transport in congenital heart disease: Influence of fetal haemoglobin red cell pH and 2,3-diphosphyglycerate. Pediat. Res. 10 (1976) 566

[11] WEISS, R. R., M. S. ROGINSKY, L. I. MANN, A. MELBER, J. B. BACHOHK, N. TEJANI, A. BHAKTHAVATHSALAM, M. I. EVANS: Erythrocyte, 2,3-diphosphoglycerate in normal and hypertensive gravid women and their newborn infants. Amer. J. Obstet. Gynec. 124 (1976) 692

Received May 11, 1982. Revised June 14, 1982. Accepted October 19, 1982.

R. G. Farquharson, M. B., Ch. B. M. R. C. O.G. Dept. of Obstetrics \& Gynaecology Welsh National School of Medicine Heathpark Cardiff, Wales Great Britain 